\title{
Guidance for Improving Life-Cycle Design and Management of Milk Packaging
}

\author{
Gregory A. Keoleian \\ Center for Sustainable Systems \\ University of Michigan \\ Ann Arbor, MI, USA \\ David V. Spitzley \\ Battelle Memorial Institute \\ Columbus, OH, USA
}

\section{Keywords}

life-cycle costs

life-cycle design

life-cycle energy

milk packaging

performance evaluation

solid waste

Address correspondence to: Gregory A. Keoleian Center for Sustainable Systems

University of Michigan

Dana Building 430 E. University

Ann Arbor, MI 48109-1115, USA

Phone: (734) 764-3194

Fax: (734) 647-5841

gregak@umich.edu

C Copyright 1999 by the Massachusetts Institute of Technology and Yale University

厂

\section{Summary}

Life-cycle inventory and cost-analysis tools applied to milk packaging offer guidelines for achieving better environmental design and management of these systems. Life-cycle solid waste, energy, and costs were analyzed for seven systems including single-use and refillable glass bottles, singleuse and refillable high-density polyethylene (HDPE) bottles, paperboard gable-top cartons, linear low-density polyethylene (LLDPE) flexible pouches, and polycarbonate refillable bottles on a basis of I,000 gal of milk delivered. In addition, performance requirements were also investigated that highlighted potential barriers and trade-offs for environmentally preferable alternatives. Sensitivity analyses, indicated that material production energy, postconsumer solid waste, and empty container costs were key parameters for predicting life-cycle burdens and costs. Recent trends in recycling rates, tipping fees, and recycled materials market value had minimal effect on the results. Inventory model results for life-cycle solid waste and energy indicated the same rank order as results from previously published life-cycle inventory studies of container systems.

Refillable HDPE and polycarbonate, and the flexible pouch were identified as the most environmentally preferable with respect to life-cycle energy and solid waste. The greater market penetration of these containers may be limited by performance issues such as empty container storage, handling requirements, and deposit fees for refillables, and resealability and puncture resistance for the pouch. 


\section{Introduction}

Packaging is a fundamental element of almost every product system. Although product containment, protection, aesthetics, and information provision are the primary requirements influencing packaging design, packaging has also received significant environmental scrutiny over the last two decades. In particular, postconsumer packaging waste has been targeted for reduction by manufacturers, consumers, and policy makers. Postconsumer solid waste reduction represents an important opportunity for environmental improvement; however, this metric provides only a partial characterization of the total environmental burden of the package. Life-cycle assessment (U.S. EPA 1995; SETAC 1993) represents a more comprehensive environmental assessment of a packaging system by addressing other environmental burdens such as energy and raw material consumption, as well as air and water pollutant emissions. These burdens are evaluated in the material production, manufacturing, use, and end-of-life management phases of the packaging life cycle.

A wide range of life-cycle assessments (LCAs) of packaging systems have been conducted (Dover et al. 1993; Kooijman 1993; Kuta et al. 1995; Midwest Research Institute 1976; Deloitte and Touche 1991; Franklin Associates 1991; Lundholm and Sundstrom 1985; Boustead 1995; Swiss FOEFL 1991, 1996) to better understand the environmental profile of alternative packaging systems. However, full integration of environmental issues into design, management, and policy decisions that influence packaging has been limited in scope. In addition to characterizing the environmental burdens related to packaging systems, improving the sustainability of these systems also requires a better understanding of other key factors affecting their management. These factors include a complex set of economic, performance, and regulatory/policy requirements. The life-cycle design framework provides a systems-oriented method for analyzing these multiple and often conflicting objectives (Keoleian et al. 1995; Keoleian and Menerey 1993a). This paper evaluates the environmental, cost, and performance profiles of milk packaging alternatives to develop specific design and management guidelines. Inventory and cost models were developed to measure the life-cycle energy, solid waste, and costs for seven alternative milk packaging systems. Sensitivity analyses of key model parameters were conducted, and inventory model results were compared with results from previously published studies. In addition, performance requirements were examined and trade-offs among system requirements were identified.

\section{Methodology}

\section{Product System}

The methodology for a comparative assessment of milk packaging begins with a clear definition of the product system under investigation. To analyze milk container design and management, seven milk containers including single-use and refillable glass bottles, single-use and refillable high-density polyethylene (HDPE) bottles, paperboard gable-top cartons, linear low density polyethylene (LLDPE) flexible pouches, and polycarbonate bottles were investigated. Container mass and U.S. national average recycling rates for each container are presented in table 1 . Sensitivity analyses of key product system parameters including trippage rates, container mass, landfill tipping fees, recycled material market value, and recycle rates were conducted. Table 2 provides data on the market value of recycled HDPE and glass between 1995 and 1997.

This study considered the life-cycle aspects of milk packaging for sale to households. Packages used for the delivery of fresh dairy milk were selected for study. Systems for delivering milk to on-site users, such as school lunch programs, were not included in this study. Additionally, this study did not address impacts associated with beverage production and filling. Data on trippage rates for refillable containers varied considerably depending on the means of distribution and container material. Trippage for glass refillable bottles has been reported to average between 20 and 30 trips (Swope 1995; Calder Dairy 1997; Oberwise Dairy 1997), but a milk bottle manufacturer indicated values range from less than 10 for milk sold by large grocery chains to 20 to 35 for dairies that own retail stores to 30 to 50 for home-delivered milk (Stanpac 1997). 
Table I Mass and U.S. national recycling rates for container systems (U.S. EPA 1997)

\begin{tabular}{|c|c|c|c|c|c|}
\hline \multirow[t]{2}{*}{ Container } & \multirow[t]{2}{*}{$\operatorname{Mass}^{a}$ ( $g /$ container $)$} & \multicolumn{4}{|c|}{ Recycling Rate (\%) } \\
\hline & & 1995 & 1994 & 1993 & 1992 \\
\hline \multicolumn{6}{|c|}{ One-half-gal (1.9 L) Containers } \\
\hline \multicolumn{6}{|c|}{ Glass bottle } \\
\hline Refillable & $923.0^{c}$ & 21.6 & 19.8 & 19.9 & 21.4 \\
\hline Single use & $559.0^{\mathrm{b}}$ & 21.6 & 19.8 & 19.9 & 21.4 \\
\hline \multicolumn{6}{|l|}{ HDPE bottle } \\
\hline Refillable & $134.0^{c}$ & 30.2 & 29.3 & 24.1 & 21.1 \\
\hline Single use & $45.2^{\mathrm{d}}$ & 30.2 & 29.3 & 24.1 & 21.1 \\
\hline \multicolumn{6}{|l|}{ LLDPE pouch } \\
\hline Single use & $10.4^{b}$ & $\mathrm{~g}$ & & & \\
\hline \multicolumn{6}{|c|}{ Paperboard carton } \\
\hline Single use & $64.5^{\mathrm{d}}$ & Neg. & Neg. & Neg. & Neg. \\
\hline \multicolumn{6}{|c|}{ Polycarbonate bottle } \\
\hline Refillable & $121.9^{\mathrm{e}}$ & $\mathrm{g}$ & & & \\
\hline \multicolumn{6}{|c|}{ One-gal (3.8 L) Containers } \\
\hline \multicolumn{6}{|c|}{ Glass bottle } \\
\hline Refillable & $1464.0^{c}$ & 21.6 & 19.8 & 19.9 & 21.4 \\
\hline \multicolumn{6}{|l|}{ HDPE bottle } \\
\hline Refillable & $168.0^{c}$ & 30.2 & 29.3 & 24.1 & 21.1 \\
\hline Single use & $64.2^{\mathrm{d}}$ & 30.2 & 29.3 & 24.1 & 21.1 \\
\hline \multicolumn{6}{|c|}{ Paperboard carton } \\
\hline Single use & $113.0^{\mathrm{d}}$ & Neg. & Neg. & Neg. & Neg. \\
\hline \multicolumn{6}{|c|}{ a Container mass includes caps and labels. } \\
\hline \multicolumn{6}{|c|}{ b Container mass based on conversation with industry representative. } \\
\hline \multicolumn{6}{|c|}{ c Source: (Midwest Research Institute 1976). } \\
\hline \multicolumn{6}{|c|}{ d Source: (Franklin Associates 1991). } \\
\hline \multicolumn{6}{|c|}{ e Source: (Saphire 1994). } \\
\hline $\begin{array}{l}{ }^{f} \text { The LLDPE pou } \\
\text { production consis }\end{array}$ & $\begin{array}{l}\text { e pouch produced in a } \\
\text { of } 80 \% \text { LLDPE with } 2\end{array}$ & $\begin{array}{l}\text { n-fill-se } \\
\text { low-de }\end{array}$ & $\begin{array}{l}\text { inuous } \\
\text { olyethyl }\end{array}$ & $\begin{array}{l}\text { on. The } \\
\text { DPE). }\end{array}$ & sed for pouch \\
\hline
\end{tabular}

For polycarbonate, trippage was reported to average 50 trips (Swope 1995). A dairy in Saratoga Springs, New York, indicated that polycarbonate bottle trippage was approximately 12 trips for grocery store retail due in large part to the lack of returns made by customers. This dairy, however, reports that lunch programs yielded a trippage of about 100 trips (Stewart's Dairy 1997).

As of 1990, HDPE bottles dominated the U.S. household milk container market with a 68\% (volume basis) share, whereas paperboard (gable-top) cartons commanded 32\% of the market. All other milk containers had a less than 1\% share (HarborSide Research 1994). Interestingly, the Canadian market is quite differ-
Table 2 Recycled material value

\begin{tabular}{lcc}
\hline & HDPE $(\$ / \mathrm{kg})$ & Glass $(\$ / \mathrm{kg})$ \\
\hline Jan. 1995 & 0.44 & 0.06 \\
Apr. 1995 & 0.60 & 0.05 \\
July 1995 & 0.42 & 0.05 \\
Oct. 1995 & 0.31 & 0.05 \\
Jan. 1996 & 0.24 & 0.05 \\
Apr. 1996 & 0.20 & 0.06 \\
July 1996 & 0.24 & 0.05 \\
Oct. 1996 & 0.26 & 0.05 \\
Jan. 1997 & 0.33 & 0.05 \\
Apr. 1997 & 0.35 & 0.04 \\
July 1997 & 0.35 & 0.04 \\
Oct. 1997 & 0.37 & 0.04 \\
\hline
\end{tabular}

Source: Recycling Times 1995, 1997. 
ent: The flexible pouch claimed a 55\% market share in 1988 (Erickson 1988), which had increased to $83 \%$ in 1995 (EPIC 1997). This discrepancy, along with historical trends, makes many industry analysts believe that there is potential for change in the U.S. dairy market (Erickson 1988).

A functional unit of 1,000 gal (3,785.4 liters) of delivered milk was used to compare containers on an equivalent use basis. This basis was used for all environmental and cost assessments unless otherwise indicated. By contrast the performance assessment is strictly qualitative in nature.

\section{Environmental Assessment}

An inventory model was developed to explore the sensitivity of the life-cycle energy and solid waste burdens to changes in key parameters. The inventory model used 1990 and 1996 material production data sets published by a single source (Ecobalance of Packaging Materials; Swiss FOEFL 1991, 1996) with the exception of polycarbonate, which comes from Franklin (1990) and Boustead (1997). The inventory model utilized published data (PPI 1995), when appropriate, to evaluate the energy required for container formation. The energy used and solid waste generated by bottle washing for refillables were determined from Midwest Research Institute (1976) and compared with recent data on steam requirements for washing equipment (Dostal \& Lowey Manufacturing Company 1997). Fuel economy (single-unit diesel truck) and the solid waste generation factor for fuel production for the 120-mile transport distance between the dairy and retail stores were obtained from Franklin Associates (1992). Transportation energy was modeled assuming a linear relationship between weight and fuel consumption; more precise modeling was beyond the scope of this study. For example, the energy factor for a single-unit truck is 3,136 Btu/tonmile $(2.266 \mathrm{MJ} / 1,000 \mathrm{~kg}-\mathrm{km})$, and this factor assumed that trucks returned empty to their starting point. For refillable containers the transportation energy for back hauling empty containers was also inventoried. In the container end-of-life stage the energy required for postconsumer container collection, recycling, and disposal were taken from Franklin Associates (1994). The end-of-life solid waste was determined based on the container weight and national average data for the percentage of containers recovered for recycling and the fraction of municipal solid waste incinerated, which is 16\% (US EPA 1996).

Sensitivity analyses were performed to explore the effects of container weight on life-cycle energy and solid waste, and the effects of postconsumer recycling rates on life-cycle solid waste. The environmental assessment of alternative milk containers, presented here, includes results from previously published life-cycle inventory studies (Midwest Research Institute 1976, Franklin Associates 1991). These results are compared with model results. A larger data set for other beverage container systems studied by the authors is reported elsewhere (Keoleian et al. 1997).

The availability of published U.S. or North American material production inventory data is currently very limited. Consequently, this investigation relied heavily on European material production data. Production processes are not expected to differ significantly between Europe and the United States for the materials investigated herein. Electricity production efficiencies for Europe and the United States are very comparable relative to other inventory parameters such as air pollutant emission factors; hence this factor may not strongly affect the representativeness of the European energy data for U.S. conditions. For example, the electricity production efficiency for the national grid in the United States has been reported as 0.32 (Franklin Associates 1992), whereas the efficiency for the Union for the Connection of Production and Transportation of Electricity (UCPTE) was found to be 0.378 (Swiss FOEFL 1991). Regional differences in electricity production within the United States and Europe, however, are much greater than this difference and could be significant. An analysis of the electricity supply system in the United States indicated that the electricity production efficiency varies between $22 \%$ and $47 \%$ across the ten regional grids as defined by the North American Electric Reliability Council (Boustead and Yaros 1994). The influence of the electricity production efficiency is minimal because electricity accounts 
for between $1 \%$ and $28 \%$ of the total material production energies for glass, plastic resins, and paperboard.

Environmental releases could, however, differ significantly due in part to differences in environmental regulations controlling these material industries. In general, airborne emissions and water effluents data show significant variability. For example, a comparison of material production databases of two major life-cycle practitioners indicated that the air and water emissions data varied by as much as $187 \%$ (Keoleian and McDaniel 1997). ${ }^{1}$ For this reason airborne and waterborne emissions data were not incorporated in this environmental analysis.

\section{Cost Assessment}

The life-cycle costs analyzed for each container system include empty container costs, filling costs, transportation costs, and end-of-life management costs. Empty container costs were evaluated based on the price paid by fillers for enough containers to deliver 1,000 gal of milk. Filling costs accounted for amortized equipment costs only; labor and utility costs were not evaluated. Labor and utility cost data were not available because they were regarded as proprietary by the dairy industry. The cost of transportation fuel was estimated for distributing full containers to retail locations and for the return of empty trucks back to their starting point. Back hauls of empty containers for refillables were also included in the cost of transportation to retail. Model parameters used for the transportation cost analysis are reported elsewhere (Keoleian et al. 1997).

Finally, the end-of-life management costs were determined for each container. End-of-life management costs included collection, material or energy recovery costs, and landfill disposal costs. Material recovery costs assumed curbside collection and accounted for both the material processing costs at a recycling facility and the market value of recovered materials. Waste-toenergy recovery costs were also estimated by accounting for the energy embodied in each combustible container. The cost of disposing of the remaining postconsumer wastes not recycled or incinerated were then calculated using an av- erage tipping fee for sanitary landfill disposition of municipal solid waste (MSW) in the U.S. reported by the National Solid Waste Management Association of \$30.25/ton (June 1995). Sensitivity analyses were conducted to investigate the effects of volatility in recycled material markets and solid waste tipping fees on life-cycle results. Recent national average tipping fees from 1993 to 1996 were obtained from BioCycle, and the regional variation in tipping fees for 1996 were also examined. Secondary material prices for glass and HDPE between January 1995 and October 1997 were obtained from Recycling Times.

The total life-cycle cost is the sum of empty container cost, filling equipment cost, cost of transportation to retail, and end-of-life management costs. Milk retail prices were not used to estimate relative costs of alternative milk packaging. The cost for packaging is not always accurately reflected in the retail price because milk products are often merchandised as loss leaders ${ }^{2}$ with a very low and variable profit margin.

\section{Performance Assessment}

Performance requirements define the functional attributes of a product system. A literature survey revealed that six functional attributes significantly influence milk package design and selection. These performance requirements are container clarity, burst/shatter resistance, ease of opening, weight, resealability, and handling of empty refillable containers (Dairy Industries International 1994; Dexheimer 1993; Sfiligoj 1994; Urbanski 1991). These attributes are relevant to many stakeholders of the milk packaging life cycle including package designers, dairies, distributors, retailers, and consumers. Several potentially important criteria were not evaluated, such as barrier properties, taste characteristics, and aesthetics (Urbanski 1991; Sfiligoj 1994; Saphire 1994).

After the literature survey was completed, each container was subjectively evaluated, based on the authors' judgment, for the six performance measures and ranked as follows: good (+), neutral $(0)$, or poor $(-)$. In this analysis each of the six criteria was weighted equally to determine an overall performance score. Stakeholder analysis including focused market research 
would establish a more concrete valuation system and ranking of performance criteria.

\section{Results and Discussion}

This section presents the environmental, cost, and performance characteristics of the seven milk packaging systems investigated. In reviewing these results, trade-offs among the alternatives begin to emerge and provide some insight into the relative success of these packaging systems in the market. Guidelines are also formulated based on the environmental and cost assessments to enhance milk packaging design and management decisions.

\section{Environmental Assessment}

\section{Energy Consumption}

Table 3 presents the total life-cycle energy consumption for each container based on previous studies and the inventory model using 1990 and 1996 (1997 for polycarbonate) material production data sets. Model results using the most recent material production data indicate the energy use for refillable containers per 1,000 gal of milk delivered ranged from $670 \mathrm{MJ}$, for 50 -trip 1 gal refillable HDPE bottles, to 7,200 MJ, for a 5trip 0.5-gal refillable polycarbonate bottle. Single-use containers per 1,000 gal of milk delivered consumed between 2,060 MJ, for a 0.5-gal flexible pouch, and 15,300 MJ, for a 0.5-gal glass bottle. Refill rates have a dramatic effect on the total life-cycle energy consumption of milk containers. An individual refillable container is generally more material-intensive relative to a single-use container of the same design and material type. As container reuse rate increases, container production energy becomes less significant on a unit volume delivered basis. The total life-cycle energy approaches the sum of the washing, filling, and transport energies in the limit as the refill rate increases.

The inventory model, using 1990 and 1996 material production data sets, corroborated results from previous studies. The rank order of container systems for life-cycle solid waste and energy was consistent among studies. In general, more recent inventory data sources (1990 and 1996) indicated a lower material production energy that accounts for the lower total life-cycle energy computed from the model compared to previous studies. Reasons for these differences may include improvements in process efficiency, energy supply efficiencies, and LCA methods. Model results based on the 1990 inventory data set did not differ significantly from the 1996 model case.

As is apparent from table 3 , material production energy constitutes the majority of many containers' life-cycle energy inputs. On average, material production consumes $93 \%, 89 \%$, and $90 \%$ of total life-cycle energy for single-use milk containers for the previously published studies, for the model results based on the 1990 data set and for the model results based on the 1996 data set, respectively. For the high trippage refillable containers based on model results with the 1996 data set, this percentage is only 36 , which is expected due to the increased importance of washing and transportation at higher refill rates.

Model predictions for the effect of container weight reduction on the life-cycle energy are shown in table 4 . In general, table 4 shows a strong correlation between weight reduction and lifecycle energy reduction. Some beverage container packaging has undergone significant weight reductions (Porter 1993). Making containers lighter is limited, however, because all containers must meet minimum strength requirements, particularly refillable containers. No weight reduction for glass refillable bottles was found in comparing 1976 data (Midwest Research Institute 1976) to current bottle masses (Keoleian 1997). Specific weight reduction data were not available for other milk containers.

\section{Solid Waste Generation}

The total life-cycle solid waste is presented in table 5 for each milk container. Model results assuming a zero postconsumer recycling rate agreed well with results from previous studies that did not account for postconsumer recycling. The model using the 1996 material production data set and 1995 recycling rates indicated that the HDPE 1-gal 50-trip refillable bottle generated the least life-cycle solid waste $(4 \mathrm{~kg} / 1,000$ gal), whereas the single-use glass container generated the most life-cycle solid waste $(951 \mathrm{~kg} /$ $1,000 \mathrm{gal})$. The relatively small difference between the 1996 model case and previous studies 
Table 3 Comparison of material production and total life cycle energy per 1.000 gal of milk delivered from previous studies with model results using 1990 and 1996 inventory data sets

\begin{tabular}{|c|c|c|c|c|c|c|c|c|}
\hline & \multicolumn{4}{|c|}{ Previous studies } & \multicolumn{2}{|c|}{$\begin{array}{l}\text { Model results } \\
\text { (1996)* }\end{array}$} & \multicolumn{2}{|c|}{$\begin{array}{l}\text { Model results } \\
(1990) * *\end{array}$} \\
\hline & & $\begin{array}{l}\text { Mat. } \\
\text { prod. }\end{array}$ & Total & Source & $\begin{array}{l}\text { Mat. } \\
\text { prod. }\end{array}$ & Total & $\begin{array}{l}\text { Mat. } \\
\text { prod. }\end{array}$ & Total \\
\hline \multicolumn{9}{|c|}{ One-half-gal Containers } \\
\hline \multicolumn{9}{|c|}{ Glass bottle } \\
\hline \multirow[t]{3}{*}{ Refillable } & 30 trip & & & & 780 & 2,810 & 590 & 2,610 \\
\hline & 20 trip & 1,910 & 3,900 & (MRI 1976) & 1,170 & 3,220 & 880 & 2,920 \\
\hline & 5 trip & 8,000 & 9,940 & (MRI 1976) & 4,690 & 6,910 & 3,500 & 5,730 \\
\hline Single use & & & & & 14,130 & 15,300 & 10,590 & 11,760 \\
\hline \multicolumn{9}{|l|}{ HDPE bottle } \\
\hline \multirow[t]{3}{*}{ Refillable } & 50 trip & 470 & 2,320 & (MRI 1976) & 430 & 1,140 & 360 & 1,070 \\
\hline & 20 trip & 1,240 & 3,290 & (MRI 1976) & 1,070 & 1,890 & 890 & 1,710 \\
\hline & 5 trip & 4,960 & 8,140 & (MRI 1976) & 4,270 & 5,670 & 3,560 & 4,960 \\
\hline \multicolumn{2}{|c|}{ Single use } & 7,920 & 8,250 & $\begin{array}{l}\text { (Franklin } \\
1991 \text { ) }\end{array}$ & 7,220 & 8,570 & 6,030 & 7,370 \\
\hline \multicolumn{9}{|c|}{ Gable-top carton } \\
\hline \multicolumn{2}{|c|}{ Single use } & & 8,040 & $\begin{array}{l}\text { (Franklin } \\
\text { 1991) }\end{array}$ & 6,860 & 7,000 & 6,400 & 6,530 \\
\hline \multicolumn{9}{|c|}{ Polycarbonate bottle } \\
\hline \multirow[t]{3}{*}{ Refillable } & 50 trip & & & & 570 & 1,270 & 830 & 1,540 \\
\hline & 20 trip & & & & 1,410 & 2,260 & 2,080 & 2,930 \\
\hline & 5 trip & & & & 5,660 & 7,200 & 8,340 & 9,890 \\
\hline \multicolumn{9}{|c|}{ Flexible pouch } \\
\hline Single use & & & & & 1,750 & 2,060 & 1,660 & 1,980 \\
\hline \multicolumn{9}{|c|}{ One-Gal Containers } \\
\hline \multicolumn{9}{|c|}{ Glass bottle } \\
\hline \multirow[t]{3}{*}{ Refillable } & 30 trip & & & & 620 & 2,120 & 460 & 1,960 \\
\hline & 20 trip & 1,500 & 3,060 & (MRI 1976) & 920 & 2,440 & 690 & 2,210 \\
\hline & 5 trip & 6,360 & 7,820 & (MRI 1976) & 3,700 & 5,350 & 2,770 & 4,420 \\
\hline \multicolumn{9}{|c|}{ Gable-top carton } \\
\hline Single use & & & 7,040 & $\begin{array}{l}\text { (Franklin } \\
\text { 1991) }\end{array}$ & 6,010 & 6,130 & 5,610 & 5,720 \\
\hline \multicolumn{9}{|l|}{ HDPE bottle } \\
\hline \multirow[t]{3}{*}{ Refillable } & 50 trip & 300 & 1,630 & (MRI 1976) & 270 & 670 & 220 & 630 \\
\hline & 20 trip & 780 & 2,240 & (MRI 1976) & 670 & 1,150 & 560 & 1,040 \\
\hline & 5 trip & 3,110 & 5,210 & (MRI 1976) & 2,680 & 3,520 & 2,240 & 3,080 \\
\hline Single use & & 5,620 & 6,220 & $\begin{array}{l}\text { (Franklin } \\
\text { 1991) }\end{array}$ & 5,150 & 6,110 & 4,300 & 5,260 \\
\hline
\end{tabular}

*Material production source: (Swiss FOEFL 1991), (Franklin 1990) for polycarbonate.

** Material production source: (Swiss FOEFL 1996), (Boustead 1997) for polycarbonate. 
Table 4 Effects of container weight reduction on total life-cycle energy use and solid waste per 1,000 gal of milk delivered

\begin{tabular}{|c|c|c|c|c|c|c|c|}
\hline & & \multicolumn{3}{|c|}{$\begin{array}{l}\text { Life cycle energy use, } \\
\text { MJ (\% change from base) }\end{array}$} & \multicolumn{3}{|c|}{$\begin{array}{c}\text { Life cycle solid waste, } \\
\mathrm{kg}(\% \text { change from base })\end{array}$} \\
\hline & & Base & $\begin{array}{l}10 \% \\
\text { reduction* }\end{array}$ & $\begin{array}{c}25 \% \\
\text { reduction** }\end{array}$ & Base & $\begin{array}{c}10 \% \\
\text { reduction* }\end{array}$ & $\begin{array}{c}25 \% \\
\text { reduction** }\end{array}$ \\
\hline \multicolumn{8}{|c|}{ One-half-gal Containers } \\
\hline \multicolumn{8}{|c|}{ Glass bottle } \\
\hline \multirow[t]{3}{*}{ Refillable } & 30 trip & 2,810 & $2,570(9 \%)$ & $2,210(21 \%)$ & 68 & $61(9 \%)$ & $51(24 \%)$ \\
\hline & 20 trip & 3,220 & $2,940(9 \%)$ & $2,510(22 \%)$ & 100 & $91(9 \%)$ & $76(24 \%)$ \\
\hline & 5 trip & 6,910 & $6,260(9 \%)$ & $5,280(24 \%)$ & 396 & $357(10 \%)$ & $298(25 \%)$ \\
\hline Single use & & 11,760 & $10,590(10 \%)$ & $8,820(25 \%)$ & 1,190 & $1,070(10 \%)$ & $894(25 \%)$ \\
\hline \multicolumn{8}{|c|}{ 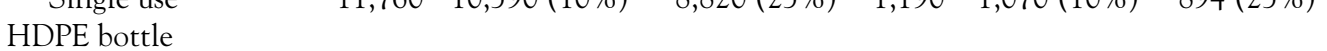 } \\
\hline \multirow[t]{3}{*}{ Refillable } & 50 trip & 1,140 & $1,060(6 \%)$ & $950(16 \%)$ & 7 & $6(7 \%)$ & $6(14 \%)$ \\
\hline & 20 trip & 1,890 & $1,740(8 \%)$ & $1,520(20 \%)$ & 14 & $13(7 \%)$ & $11(21 \%)$ \\
\hline & 5 trip & 5,670 & $5,140(9 \%)$ & $4,350(23 \%)$ & 49 & $44(10 \%)$ & $37(24 \%)$ \\
\hline Single use & & 8,570 & $7,710(10 \%)$ & $6,420(25 \%)$ & 79 & $71(10 \%)$ & $59(25 \%)$ \\
\hline \multicolumn{8}{|c|}{ Gable-top carton } \\
\hline Single use & & 7,000 & $6,300(10 \%)$ & $5,250(25 \%)$ & 140 & $122(10 \%)$ & $102(25 \%)$ \\
\hline \multicolumn{8}{|c|}{ Polycarbonate bottle } \\
\hline \multirow[t]{3}{*}{ Refillable } & 50 trip & 1,270 & $1,180(7 \%)$ & $1,050(17 \%)$ & 7 & $7(7 \%)$ & $6(14 \%)$ \\
\hline & 20 trip & 2,260 & $2,070(8 \%)$ & $1,790(21 \%)$ & 15 & $14(7 \%)$ & $12(20 \%)$ \\
\hline & 5 trip & 7,200 & $6,520(9 \%)$ & $5,500(24 \%)$ & 53 & $48(9 \%)$ & $40(25 \%)$ \\
\hline \multicolumn{8}{|c|}{ Flexible pouch } \\
\hline Single use & & 2,060 & $1,860(10 \%)$ & $1,550(25 \%)$ & 18 & $16(10 \%)$ & $13(25 \%)$ \\
\hline \multicolumn{8}{|c|}{ One-gal Containers } \\
\hline \multicolumn{8}{|l|}{ Glass bottle } \\
\hline \multirow[t]{3}{*}{ Refillable } & 30 trip & 2,120 & $1,920(9 \%)$ & $1,640(23 \%)$ & 54 & $49(9 \%)$ & $41(24 \%)$ \\
\hline & 20 trip & 2,440 & $2,220(9 \%)$ & $1,880(23 \%)$ & 80 & $72(9 \%)$ & $60(24 \%)$ \\
\hline & 5 trip & 5,350 & $4,830(10 \%)$ & $4,060(24 \%)$ & 310 & $283(10 \%)$ & $236(25 \%)$ \\
\hline \multicolumn{8}{|c|}{ Gable-top carton } \\
\hline Single use & & 6,130 & $5,520(10 \%)$ & $4,600(25 \%)$ & 120 & $107(10 \%)$ & $89(25 \%)$ \\
\hline \multicolumn{8}{|l|}{ HDPE bottle } \\
\hline \multirow[t]{3}{*}{ Refillable } & 50 trip & 670 & $620(7 \%)$ & $560(17 \%)$ & 5 & $4(6 \%)$ & $4(20 \%)$ \\
\hline & 20 trip & 1,150 & $1,050(8 \%)$ & $910(20 \%)$ & 9 & $8(8 \%)$ & $7(22 \%)$ \\
\hline & 5 trip & 3,520 & $3,190(9 \%)$ & $2,700(24 \%)$ & 31 & $28(10 \%)$ & $24(23 \%)$ \\
\hline Single use & & 6,110 & $5,500(10 \%)$ & $4,580(25 \%)$ & 56 & $50(10 \%)$ & $42(25 \%)$ \\
\hline
\end{tabular}

Note: All results generated using the life-cycle inventory model.

* Theoretical $10 \%$ reduction in container weight.

** Theoretical $25 \%$ reduction in container weight. 
is due to differences in the solid waste factors for material production, transportation, and washing. For single-use milk containers, postconsumer waste accounts for $90 \%$ of life-cycle solid waste on average. In the case of refillable containers, postconsumer waste accounts for $74 \%$ of the life-cycle solid waste. The difference results from the waste associated with the washing and additional transportation requirements for the refillable containers.

The effects of recent changes in HDPE and glass recycling rates on total life-cycle solid waste are also indicated in table 5 . The corresponding recycling rates are shown in table 1 . In general, the variation in the recent national average recycling rates did not have a dramatic effect on the total life-cycle solid waste. Strong correlations exist for both container weight reduction (table 4) and postconsumer recycling with the total life-cycle solid waste. Weight reduction of the container, a source reduction strategy, will have a slightly greater impact on total life-cycle solid waste reduction than is observed for an equivalent percentage increase in the recycle rate.

\section{Cost Assessment}

The total life-cycle costs for each container per 1,000 gal of milk delivered are indicated in table 6 . These costs ranged from $\$ 44$ for 50 -trip refillable HDPE containers to $\$ 1,039$ for singleuse glass bottles. For the single container systems shown in table 6, empty container costs represent $79 \%$ of the total on average. Costs for refillable container systems are less dependent on empty container costs than are single-use systems. Container costs accounted for $51 \%$ of the life-cycle cost for high-trippage refillable systems. A sensitivity analysis of tipping fees on the net end-of-life cost for each container system is shown in figure 1. National average tipping fees were very steady between 1993 and 1996 (\$28/ ton in 1993 , $\$ 29 /$ ton in 1994 , $\$ 34 /$ ton in 1995 ,

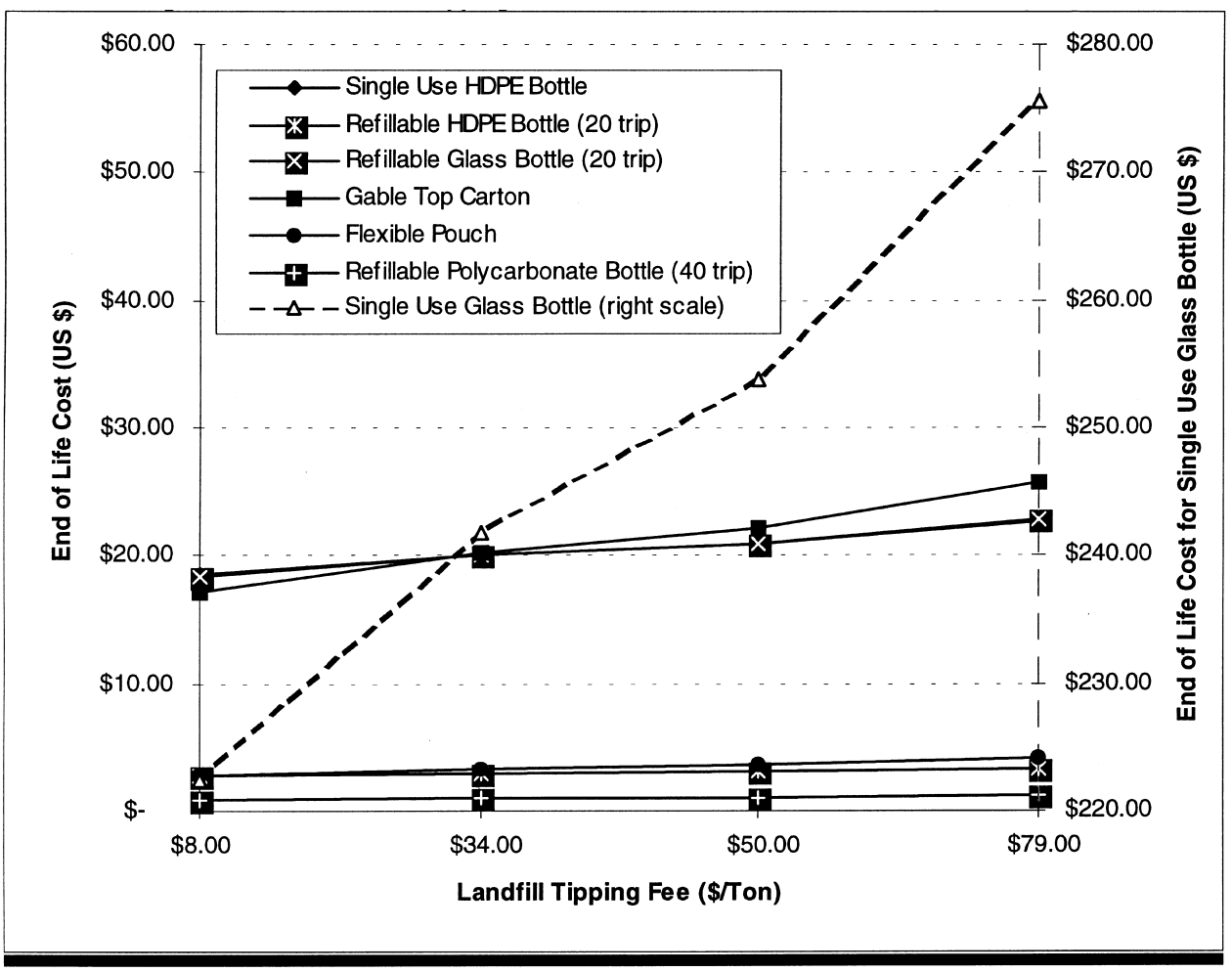

Figure I Effect of landfill tipping fee on end-of-life cost for container systems (I/2 gal containers). 
Table 5 Comparison of model results for postconsumer and total life-cycle solid waste per I,000 gal of milk delivered with previous studies, including variations in national average recycling rate

\begin{tabular}{|c|c|c|c|c|c|c|c|c|c|}
\hline & \multicolumn{4}{|c|}{ Previous studies } & \multicolumn{4}{|c|}{$\begin{array}{l}\text { Model results } \\
\text { with recycling }\end{array}$} \\
\hline & & \multicolumn{2}{|c|}{ O\% Recycling } & \multicolumn{2}{|c|}{ 0\% Recycling * } & \multirow{2}{*}{$\begin{array}{c}1995 \\
\text { Total }\end{array}$} & \multirow{2}{*}{$\begin{array}{l}1994 \\
\text { Total }\end{array}$} & \multirow{2}{*}{$\begin{array}{l}1993 \\
\text { Total }\end{array}$} & \multirow{2}{*}{$\begin{array}{l}1992 \\
\text { Total }\end{array}$} \\
\hline & & Total & Source & $\begin{array}{c}\text { Post- } \\
\text { consumer }\end{array}$ & Total & & & & \\
\hline \multirow{2}{*}{\multicolumn{10}{|c|}{ One-half-gal Containers }} \\
\hline & & & & & & & & & \\
\hline \multirow[t]{3}{*}{ Refillable } & 30 trip & & N/A & 62 & 68 & 55 & 56 & 56 & 55 \\
\hline & 20 trip & 120 & MRI 1976 & 92 & 100 & 81 & 82 & 82 & 81 \\
\hline & 5 trip & & MRI 1976 & 370 & 400 & 316 & 323 & 323 & 317 \\
\hline Single use & & & N/A & 1,120 & 1,190 & 951 & 971 & 970 & 953 \\
\hline \multicolumn{10}{|l|}{ HDPE bottle } \\
\hline \multirow[t]{3}{*}{ Refillable } & 50 trip & 11 & MRI 1976 & 5 & 7 & 5 & 5 & 5 & 6 \\
\hline & 20 trip & 19 & MRI 1976 & 11 & 14 & 10 & 10 & 10 & 11 \\
\hline & 5 trip & & MRI 1976 & 45 & 49 & 35 & 35 & 38 & 39 \\
\hline Single use & & 84 & Franklin 1991 & 76 & 79 & 56 & 57 & 60 & 63 \\
\hline \multicolumn{10}{|c|}{ Gable-top carton } \\
\hline Single use & & 140 & Franklin 1991 & 108 & 140 & Neg. & Neg. & Neg. & Neg. \\
\hline \multicolumn{10}{|c|}{ Polycarbonate bottle } \\
\hline \multirow[t]{3}{*}{ Refillable } & 50 trip & & N/A & 4 & 7 & $* *$ & $* *$ & $* *$ & $* *$ \\
\hline & 20 trip & & N/A & 5 & 15 & $* *$ & $* *$ & $* *$ & $* *$ \\
\hline & 5 trip & & N/A & 41 & 53 & $* *$ & $* *$ & $* *$ & $* *$ \\
\hline \multicolumn{10}{|c|}{ Flexible pouch } \\
\hline Single use & & & $\mathrm{N} / \mathrm{A}$ & 18 & 18 & Neg. & Neg. & Neg. & Neg. \\
\hline \multirow{2}{*}{\multicolumn{10}{|c|}{$\begin{array}{l}\text { One-gal Containers } \\
\text { Glass bottle }\end{array}$}} \\
\hline & & & & & & & & & \\
\hline \multirow{3}{*}{ Refillable } & 30 trip & & N/A & 49 & 54 & 43 & 44 & 44 & 43 \\
\hline & 20 trip & 93 & MRI 1976 & 73 & 80 & 64 & 65 & 65 & 64 \\
\hline & 5 trip & 360 & MRI 1976 & 290 & 310 & 251 & 256 & 256 & 252 \\
\hline \multicolumn{10}{|c|}{ Gable-top carton } \\
\hline Single use & & 120 & Franklin 1991 & 95 & 120 & Neg. & Neg. & Neg. & Neg. \\
\hline \multicolumn{10}{|l|}{ HDPE bottle } \\
\hline \multirow[t]{3}{*}{ Refillable } & 50 trip & 7 & MRI 1976 & 3 & 5 & 4 & 4 & 4 & 4 \\
\hline & 20 trip & & MRI 1976 & 7 & 9 & 7 & 7 & 7 & 7 \\
\hline & 5 trip & & MRI 1976 & 28 & 31 & 22 & 23 & 24 & 25 \\
\hline Single use & & 62 & Franklin 1991 & 54 & 56 & 40 & 40 & 43 & 45 \\
\hline
\end{tabular}

*Accounting for $16 \%$ incineration rate.

**Although the polycarbonate bottle manufacturer has a bottle buy-back program, the percentage of discarded containers recycled through this system is not known.

Neg. These containers reported to have a negligible recycle rate during the years studied.

N/A. Data not available.

Recycle rates for HDPE and glass provided in table 1. 
Table 6 Life-cycle costs of 0.5-gal milk containers (values rounded to the nearest dollar) ( $\$ / 1000$ gal)

\begin{tabular}{|c|c|c|c|c|c|c|}
\hline Container & Trips & $\begin{array}{c}\text { Empty } \\
\text { container, } \$\end{array}$ & $\begin{array}{l}\% \text { of } \\
\text { total }\end{array}$ & $\begin{array}{l}\text { Transportation/ } \\
\text { filling, } \$\end{array}$ & $\begin{array}{l}\text { End of } \\
\text { life, *\$ }\end{array}$ & $\begin{array}{c}\text { Life-cycle } \\
\text { cost }, \$\end{array}$ \\
\hline \multicolumn{7}{|l|}{ Glass bottle } \\
\hline \multirow[t]{3}{*}{ Refillable } & 30 trip & 43 & 44 & 37 & 18 & 98 \\
\hline & 20 trip & 64 & 52 & 37 & 21 & 122 \\
\hline & 5 trip & 256 & 75 & 37 & 48 & 341 \\
\hline Single use & & 773 & 74 & 24 & 242 & 1,039 \\
\hline \multicolumn{7}{|l|}{ HDPE bottle } \\
\hline \multirow[t]{3}{*}{ Refillable } & 50 trip & 18 & 41 & 24 & 2 & 44 \\
\hline & 20 trip & 45 & 63 & 24 & 3 & 72 \\
\hline & 5 trip & 180 & 85 & 24 & 7 & 211 \\
\hline Single use & & 300 & 88 & 20 & 20 & 340 \\
\hline \multicolumn{7}{|l|}{ LLDPE pouch } \\
\hline Single use & & 80 & 78 & 20 & 3 & 103 \\
\hline \multicolumn{7}{|c|}{ Paperboard carton } \\
\hline Single use & & 132 & 76 & 21 & 21 & 174 \\
\hline \multicolumn{7}{|c|}{ Polycarbonate bottle } \\
\hline \multirow[t]{3}{*}{ Refillable } & 50 trip & 56 & 69 & 24 & 1 & 81 \\
\hline & 20 trip & 140 & 85 & 24 & 1 & 165 \\
\hline & 5 trip & 560 & 96 & 24 & 2 & 586 \\
\hline
\end{tabular}

*End-of-Life $=$ recycling, incineration, and landfill disposal.

and $\$ 32 /$ ton in 1996) and consequently end-oflife costs would not change significantly. The range of tipping fees shown on the abscissa in figure 1 represents the regional variation for 1995. The tipping fee over this range does have a strong effect (about 24\%) on the end-of-life cost for single-use glass. In contrast, the tipping fee, even at the extreme regional 1995 values of $\$ 8 /$ ton and $\$ 79 /$ ton has a very weak effect on the total life-cycle cost for all containers studied. The largest variation was observed for glass single-use bottles where the life-cycle cost increased by only $6 \%$ when the tipping fee was increased from $\$ 8 /$ ton to $\$ 79 /$ ton. The effects of recent fluctuations in the market value of recycled material on the end-of-life cost for each container were examined in figure 2. HDPE showed the most dramatic change; between April 1995 and April 1996 the price of recycled HDPE decreased to one-third its initial value and the end-of-life cost increased by $41 \%$. Similar to the tipping fee case, a sensitivity analysis of recycled material prices indicated that this parameter did not have a major effect on the total life-cycle costs, even though prices showed significant volatility over a 3 -year period. The greatest change was found for a single-use HDPE bottle where a $67 \%$ drop in the price of recycled HDPE led to only a 3\% increase in the total lifecycle cost. The sensitivity analysis results for the tipping fee and the recycled material market value support previous findings indicating that the total life-cycle cost is dominated by the empty container price.

Other anecdotal information regarding refillable bottles provides some insight into their limited success in the marketplace. In general, a relatively significant deposit is required on refillable bottles (generally more than 50 cents). This increase in the purchase cost of milk sold in refillable containers may discourage many customers. If the deposit is reduced, bottle return rates drop significantly and bottle replacement expenses incurred by dairies increase accordingly.

\section{Performance}

A qualitative evaluation of each milk container system is indicated in table 7. The overall performance represents an average of the scores for the six performance criteria. The HDPE refillable and single-use bottles had high scores for 


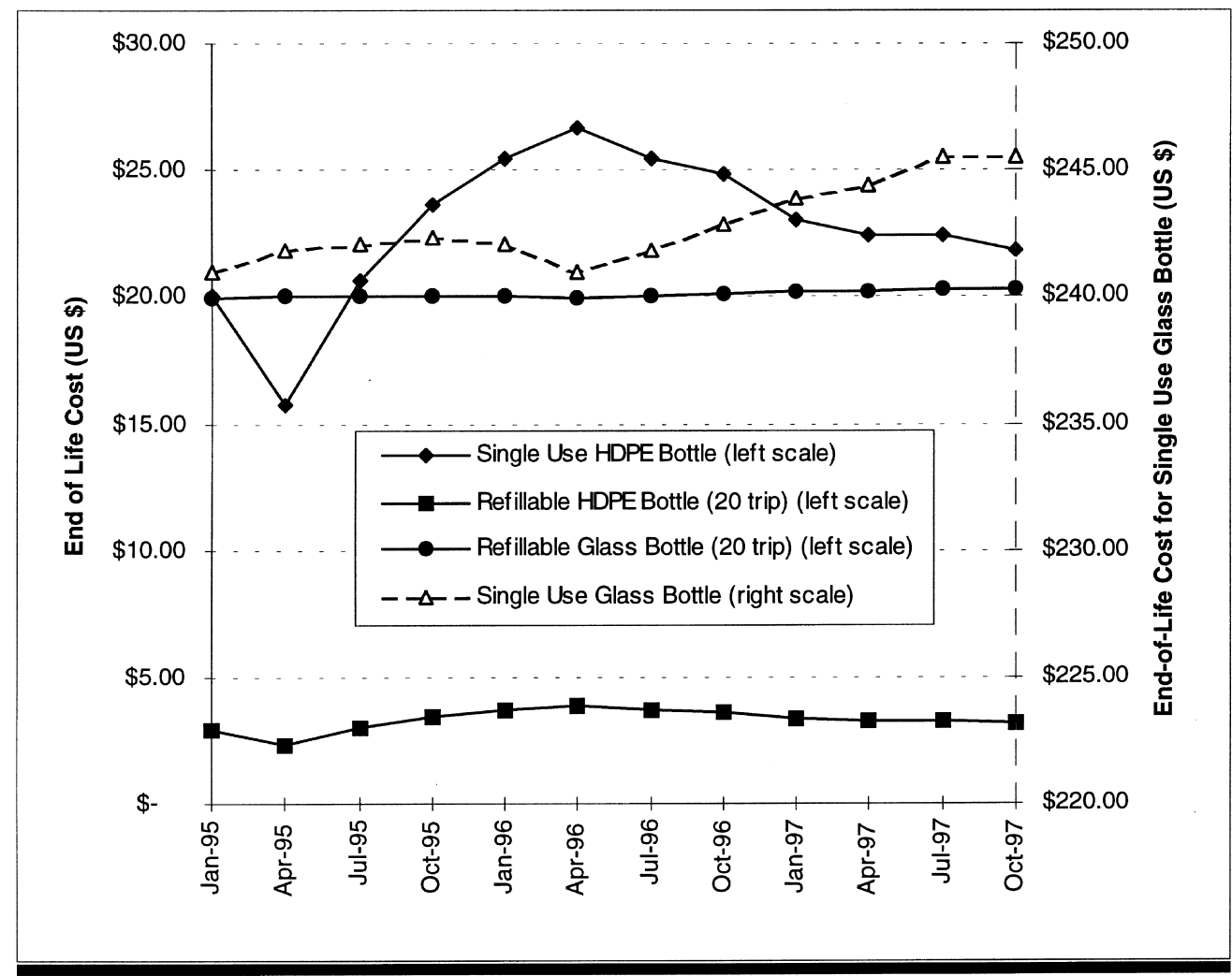

Recycled material values for HDPE and glass are shown in Table 2.

Figure 2 Trends in end-of-life cost due to variations in recycled material value between 1995 and 1997 ( I/2-gal containers). Recycled material values for HDPE and glass are shown in table 2.

most performance criteria leading to an overall best performance rating. The single-use and refillable glass containers had a low overall score because of their potential for breakage, transparency, and relatively high weight. The limitations of the paperboard carton are its potential for leakage and its difficulty in opening, particularly for the elderly (Sfiligoj 1994).

In the case of refillable containers, merchants must accommodate returns of refillable containers, whereas consumers must be responsible for rinsing and returning them to the grocery store. A return infrastructure has been established in bottle bill states, although the trend is shifting almost exclusively toward recycling nonrefillable containers. Even though returns may be considered inconvenient, nonreturnable packaging also requires some type of consumer action, either through trash disposal or recycling. The polycarbonate refillable container had simi- lar ratings as the HDPE refillable except that it is less able to block ultraviolet light, which has the potential to lead to losses in nutritional value (Dexheimer 1993).

The weak attributes of the pouch are its vulnerability to puncture and its resealability limitations. A pitcher, which must be cleaned periodically, is required to hold the pouch and facilitate pouring and storage. Thus, although currently popular in regional markets, both the pouch and refillable bottles exhibit clear performance trade-offs that limit their successful market penetration.

\section{Design Guidelines and Recommendations}

Design guidelines for milk packaging were developed from the analyses of life-cycle inventory results presented in tables 3 to 5 . Based on 
Table 7 Performance evaluation of milk packaging*

\begin{tabular}{lccccccc}
\hline Container & $\begin{array}{c}\text { Light } \\
\text { blocking }\end{array}$ & $\begin{array}{c}\text { Burst } \\
\text { resistance }\end{array}$ & $\begin{array}{c}\text { Ease of } \\
\text { opening }\end{array}$ & Weight & Resealable & $\begin{array}{c}\text { Empties } \\
\text { storage }\end{array}$ & Overall \\
\hline $\begin{array}{l}\text { Glass bottle } \\
\text { Refillable }\end{array}$ & - & - & + & - & + & - & - \\
$\quad$ Single use & - & - & + & - & + & + & - \\
$\begin{array}{l}\text { HDPE bottle } \\
\text { Refillable }\end{array}$ & 0 & + & + & + & + & - & + \\
$\quad$ Single use & 0 & + & + & + & + & + & + \\
$\begin{array}{l}\text { LLDE pouch } \\
\text { Single use }\end{array}$ & + & 0 & - & + & - & + & 0 \\
$\begin{array}{l}\text { Paperboard carton } \\
\text { Single use }\end{array}$ & + & 0 & - & + & 0 & + & 0 \\
$\begin{array}{l}\text { Polycarbonate bottle } \\
\text { Refillable }\end{array}$ & - & + & + & + & + & - & 0 \\
\hline
\end{tabular}

$*_{+}=\operatorname{good}, 0=$ neutral, $-=$ poor.

life-cycle solid waste and energy data for a variety of container systems, the following two environmental guidelines for container design are proposed:

- Minimize total life-cycle energy by minimizing material production energy, particularly for single-use containers. This can be achieved by using less energy-intensive materials and reducing the material intensity of each container. Making both single-use and refillable containers lighter will also reduce transportation energy requirements. For refillable containers, high refill rates will reduce the contribution of the material production energy to the total life-cycle energy on a unit delivered basis.

- Minimize total life-cycle solid waste by minimizing postconsumer solid waste. This can be achieved through reductions in container weight per volume delivered and through achieving high refill rates with refillable systems.

A special caveat must be stated here regarding these guidelines: They do not address environmental impacts related to air emissions and water effluents and do not distinguish between types of solid waste. In addition, resource depletion and scarcity issues for elemental flows (originating from the earth) of materials and energy were not considered. Therefore, these guidelines are limited in their ability to facilitate the design or selection of container systems with the least overall environmental impact. Special caution should be exercised when applying these guidelines to other beverage container systems; however, functionally similar systems should follow similar patterns for the distribution of solid waste and energy across the life cycle.

Another design guideline can be deduced from an analysis of life-cycle cost results. Table 6 indicates that empty container costs contributed a majority of the total life-cycle costs, consequently the following guideline is proposed:

- Minimize total life-cycle costs by minimizing empty container cost on a per-volume basis.

This can be achieved by either high trippage rate for refillable bottles or by limiting material and fabrication costs for single-use containers. Life-cycle cost represents the costs to society that are reflected in the marketplace. Externalities such as possible global warming caused by greenhouse gas emissions were not included in total life-cycle cost.

\section{Conclusions}

The life-cycle inventory and cost analysis tools were applied to milk packaging to guide environmental improvements through better design. Simplified design guidelines for improv- 
ing the environmental performance of milk packaging were recommended based on results from the inventory model developed herein and an analysis of previous life-cycle inventory studies. For single-use containers, the total life-cycle energy can be approximated by computing the material production energy of the package. For this reason, less energy-intensive materials should be encouraged along with less materialintensive containers. For refillable containers, high refill rates should be achieved to best exploit the initial energy investment in the production of the container. Life-cycle solid waste is largely determined by postconsumer packaging waste; consequently less material-intensive containers in general should be emphasized.

The packaging community does not have easy access to life-cycle inventory data or the resources to perform rigorous life-cycle inventory studies on a routine basis. The metrics and guidelines developed in this study are intended to respond to these limitations. As published life-cycle data become more widely available and techniques for impact assessment are further developed, additional metrics addressing ecological and human health consequences, caused by air pollutant emissions and water pollutant effluents, and resource depletion issues should be established for milk and juice packaging. These metrics will complement the metrics proposed here and will provide a more comprehensive measure of a packaging system's environmental performance.

Close agreement in the relative rankings of container systems was found between results from previous studies and the inventory model developed in this article. Milk packaging and beverage containers in general are relatively simple product systems to analyze because of their single-material composition. It is expected that variability among studies would be greater for more complex product systems when more assumptions and judgments must be made regarding system boundaries and allocation rules. Sensitivity and scenario analyses were useful in exploring the importance of material production inventory parameters, container mass, and recycling rates on total life-cycle energy, solid waste, and cost.

The life-cycle cost analysis showed that the empty container cost was the major determinant of total life-cycle cost, which also includes the transportation, filling, and end-of-life costs such as collection and disposal. Volatility in the market value of recycled materials and the dramatic regional variation in tipping fees did not have a significant impact on the total life-cycle cost.

Analysis of milk container systems highlighted both trade-offs and some consistent patterns for environmental, cost, and performance criteria. Refillable HDPE and polycarbonate bottles and the flexible pouch were shown to be the most environmentally preferable containers with respect to life-cycle energy and solid waste criteria. These containers were also found to have the least life-cycle costs. The strong correlation between least life-cycle cost and least lifecycle environmental burden indicates that the market system could potentially encourage these environmentally preferable containers. For this to occur, retailers would have to account for container costs more accurately in pricing milk. In other cases, significant externalities (environmental burdens) not reflected in the market system may also create a barrier for market penetration of an environmentally preferable container. The ideal container would combine the following attributes: low fabrication cost, barrier properties comparable to glass, low weight and shatter resistance afforded by plastics, resealability (screw-on top), low material production energy per unit delivered, low material production of solid waste per unit delivered, and high end-of-life recyclability (dependent on infrastructure). These characteristics apply to both single-use and refillable container systems.

Performance factors currently influence the overall viability of alternative container systems much more significantly than environmental burdens. Several performance criteria were highlighted that present potential barriers to otherwise environmentally preferable containers such as the refillable bottles and pouches. Containers that require significant changes in merchandising and/or consumer practices will encounter market resistance. Public education about the environmental merits of these systems may be required to influence their acceptance.

In addition to cost and performance, government policies and regulations can potentially influence the design of container packaging. The diverse and complex policies and regula- 
tions related to packaging systems include fees and taxes, municipal/state/federal goals, bans and mandates, recycling/waste minimization requirements, and manufacturer packaging requirements (Keoleian et al. 1997). The network of regulatory and policy incentives and constraints is not balanced in its coverage of the total life-cycle system. In particular, current policies and regulations tend to focus mainly on the recycling of postconsumer packaging waste. This emphasis could favor less environmentally preferable packaging such as single-use glass containers over a pouch system that results in less total life-cycle energy and waste. Regulations that support postconsumer solid waste minimization should be encouraged, but instruments that focus on discrete stages must be developed in a fashion that does not eliminate packaging systems that are preferable from a total life-cycle perspective. This narrow perspective was also observed for consumers whose perception of environmental performance was based on single attributes such as material type and returnability, which often conflicted with life-cycle assessments (Van Dam 1996). Glass refillable bottles were perceived to be much more environmentally preferable than plastic refillables. In general, consumers lack information about the environmental profiles of packages, and related costs, and consequently give little attention to this factor in milk purchases. The metrics established in this study can help educate the public, milk distributors, retailers, packaging designers, material suppliers, and policymakers about the environmental consequences of milk and juice packaging.

\section{Acknowledgments}

This manuscript is based on a Life Cycle Design Demonstration Project conducted with Dow Chemical Company. We would like to thank Jeff McDaniel (former graduate student researcher at the University of Michigan), Scott Noesen (Dow Project Leader), and Tony Kingsbury (Dow) for their valuable roles in this project.

This project was wholly funded by the U.S. Environmental Protection Agency under Assistance Agreement CR 822998-01-0 to the University of Michigan. Kenneth Stone is the project officer at the U.S. EPA National Risk Management Research Laboratory. The contents do not necessarily reflect the views and policies of the U.S. EPA. Mention of trade names or commercial products does not constitute endorsement or recommendation for use.

\section{Notes}

1. Editor's note: For a discussion of the influence of variation in datasets on LCA results, see E. Copius Peereboom et al., Influence of inventory data sets on life-cycle assessment results: A case study on PVC, Journal of Industrial Ecology 2(3): 109-130 (1999).

2. A loss leader is merchandise sold at or below retailer cost that draws customers into a store and is intended to create additional purchases that may not have occurred otherwise.

\section{References}

BioCycle. 1994-1997 (April issues). The state of garbage: BioCycle nationwide survey. BioCycle.

Boustead, I. 1997. Eco-profiles of the European plastics industry, Report 13: Polycarbonate. Brussels: Association of Plastics Manufacturers in Europe.

Boustead, I. 1995. Eco-profiles of the European plastics industry, report 8: Polyethylene terephthalate (PET). Brussels: Association of Plastic Manufacturers in Europe Technical and Environmental Centre.

Boustead, I. and B. R. Yaros. 1994. Electricity supply industry in North America. Resources, Conservation and Recycling 12: 121-134.

Calder Dairy. 1997. Personal communication. Lincoln Park, MI.

Dairy Industries International. 1994. NCF Sligo launches first $1.5 \mathrm{~L}$ carton. Dairy Industries International 59(6): 47.

Deloitte and Touche. 1991. Energy and environmental impact profiles in Canada of tetra brik aseptic carton and glass bottle packaging systems, Deloitte and Touche.

Dexheimer, E. 1993. Fighting the light: Campaign aims to sell more milk packaged in paperboard. Dairy Foods Magazine 94(9): 81.

Dostal \& Lowey Manufacturing Company, Inc. 1997. Personal communication. Menomonee Falls, Wis.

Dover, S., E. Madden, M. Common, and S. Boyden. 1993. Milk packaging in Australia: A case study in environmental priorities. Resources, Conservation and Recycling 9: 61-73.

EPIC. 1997. The evolution of milk packaging and the ef- 
fect on solid waste in Ontario from 1968 to 1995. Mississauga, Ontario: Environment and Plastics Industry Council.

Erickson, G. 1988. Milk in bag finds niche; saves \$. Packaging 33: 8-10.

Franklin Associates. 1990. Comparative energy evaluation of plastic products and their alternatives for the building and construction and transportation industries. Prairie Village, KS: Franklin Associates.

Franklin Associates. 1991. Resource and environmental profile analysis of high-density polyethylene and bleached paperboard gable milk containers, Prairie Village, KS: Franklin Associates.

Franklin Associates. 1992. Appendix A: Energy requirements and environmental emissions for fuel consumption, Prairie Village, KS: Franklin Associates.

Franklin Associates. 1994. The role of recycling in integrated solid waste management to the year 2000. Stamford, CT: Keep America Beautiful, Inc.

HarborSide Research. 1994. Estimated price per ton of common packages.

Keoleian, G. A. 1997. Unpublished data.

Keoleian, G. A., J. Koch, and D. Menerey. 1995. Life cycle design framework and demonstration projects: Profiles of ATETT and AlliedSignal, EPA/600/R95/107. U.S. Environmental Protection Agency, National Risk Management Research Laboratory, Cincinnati, Ohio.

Keoleian, G. A. and J. S. McDaniel. 1997. Life cycle design of instrument panels: A common sense approach. SAE International Congress and Exposition. Warrendale, PA: SAE International, Technical Paper 970695.

Keoleian, G. A. and D. Menerey. 1993. Life cycle design guidance manual: Environmental requirements and the product system. U.S. EPA, Office of Research and Development, Risk Reduction Engineering Laboratory, Cincinnati, Ohio.

Keoleian, G. A., D. V. Spitzley, and J. McDaniel. 1997. Life cycle design of milk and juice packaging, EPA 600/R-97/082 (NTIS 1-800-553-6847). U.S. Environmental Protection Agency, Office of Research and Development, National Risk Management Research Laboratory, Cincinnati, Ohio.

Kooijman, J. M. 1993. Environmental assessment of packaging: Sense and sensibility. Environmental Management 17(5): 575-586.

Kuta, C. C., D. G. Koch, C. C. Hildebrandt, and D. C. Janzen. 1995. Improvement of products and packaging through the use of life cycle analysis. Resources, Conservation and Recycling 14: 185-198.

Lundholm, M. P. and G. Sundstrom. 1985. Tetra brik aseptic environmental profile: Resource and envi- ronmental impact of tetra brik aseptic carton and of refillable glass bottles. Malmo, Sweden: Tetra Pak, 173 pp. report.

Midwest Research Institute. 1976. Resource and environmental profile analysis of five milk container systems, with selected health and economic considerations. Washington, D.C.: United States Environmental Protection Agency.

Oberwise Dairy. 1997. Personal communication. Aurora, IL.

Porter, W. J. 1993. Recycling at the crossroads. Sterling, VA: Porter and Associates.

PPI. 1995. Life-cycle inventory analysis: Thermoplastic resin fabrication conversion processes, a preliminary study. Polymer Processing Institute at Stevens Institute of Technology, Hoboken, N.J.

Recycling Times. 1995 (Jan. 24, April 18, July 25, Oct. 17), 1997 (Jan. 20, April 28, July 21, Oct. 13, 1997 issues include data on previous year). The Markets Page. Waste Age's Recycling Times.

Saphire, D. 1994. Case reopened: Reassessing refillable bottles. New York: INFORM.

SETAC. 1993. Workshop report-guidelines for life-cycle assessment: A code of practice, Pensacola, FL: Society of Environmental Toxicology and Chemistry.

Sfiligoj, E. 1994. Spouting off. Beverage World (October): 233 .

Stanpac, Inc. 1997. Personal communication. Lewiston, N.Y.

Stewart's Dairy. 1997. Personal communication. Saratoga Springs, N.Y.

Swiss FOEFL. 1991. Ecobalance of packaging materials state of 1990. Berne, Switzerland: Swiss Federal Office of Environment, Forests and Landscape.

Swiss FOEFL. 1996. Ökoinventare für Verpackungen, Berne, Switzerland: Swiss Federal Office of Environment, Forests and Landscape.

Swope, T. 1995. New wine from old bottles. The Environmental Magazine 6(4): 32-35.

Urbanski, A. 1991. Torn between two bottles; Ocean Spray test markets two beverage package sizes. Food 63 Beverage Marketing 10(11): 38.

U.S. EPA. 1995. Life cycle impact assessment: A conceptual framework, key issues, and summary of existing methods, EPA-452/R-95-002. Research Triangle Park, NC: U.S. Environmental Protection Agency, Office of Air Quality.

U.S. EPA. 1997. Characterization of municipal solid waste in the United States: 1996 update, EPA530-R-97. 015. United States Environmental Protection Agency, Solid Waste and Emergency Response.

Van Dam, Y. K. 1996. Environmental assessment of packaging: The consumer point of view. Environmental Management 20(5): 607-614. 